\title{
PENDIDIKAN KARAKTER BAGI GENERASI PENERUS BANGSA
}

\author{
Oleh: \\ Ida Ayu Gde Yadnyawati \\ yadnyawati@unhi.ac.id \\ I Nyoman Winyana \\ winyana@unhi.ac.id \\ Universitas Hindu Indonesia Denpasar
}

\begin{abstract}
ABSTRAK
Terjadinya kekacauan di dalam bertata negera ditunjukan dengan adanya penyimpangan perilaku. Penyimpangan yang melawan arus perilaku normal dan berkarakter. Ada banyak korupsi dan pencurian yang membawa kondisi tidak sesuai dengan harapan bersama. Tujuan dari artikel ini adalah peningkatan karakter generasi penerus bangsa sebagai harapan masa depan bangsa yang berkeadilan. Menempatkan peran perguruan tinggi dalam membawa mahasiswa menjadi berkarakter. Melalui pendekatan kualitatif dan beberapa pendekatan teoretis, kajian ini juga menggunakan pendekatan studi dokumentasi dan observasi di dalam memperoleh kesimpulan. Adapun temuannya menunjukan bahwa lemahnya karakteristik generasi muda sangat memungkinkan terjadinya penyelenggaraan degradasi moral dan hal itu dapat menggangu kehidupan bangsa secara umum.
\end{abstract}

Kata Kunci: Pendidikan, Karakter, Penerus Bangsa

\section{ABSTRACT}

The occurrence of chaos in the state is shown by deviations in behavior. A deviation that goes against the flow of normal behavior and character. There is a lot of corruption and theft that brings conditions not according to common expectations. The purpose of this article is to improve the character of the nation's future generations as a hope for a just future for a nation. Placing the role of universities in bringing students into character. Through a qualitative approach and several theoretical approaches, this study also uses a documentation and observation study approach in obtaining conclusions. The findings show that the weak characteristics of the younger generation make it possible to carry out moral degradation and it can disrupt the life of the nation in general.

Keywords: Education, Character, Next Generation

\section{PENDAHULUAN}

Perguruan tinggi mengemban tanggung jawab dan kewajiban yang besar, khususnya dalam melahirkan sumber daya intelektual, yang diharapkan nantinya bisa memberikan kontribusi bagi peningkatan kualitas sumber daya manusia (SDM) bangsa ini (Supardi,1997:87; dalam Wibowo, 2013:1). Kegiatan memproduksi, mengkonstruksi, dan merevitalisasi paradigma sumber daya manusia itu, agar mereka memiliki perspektif kognisi, afeksi, dan konasi yang baik di mata masyarakat sebagai bekal kehidupannya, tentu saja tidak mudah.Perguruan tinggi, dalam Bahasa Andi Trinanda (2007), tidak saja harus 
dituntut segi-segi otentitasnya secara yuridis dan eksistensial agar legitimasinya diakui oleh pemerintah dan masyarakat sebagai sebuah institusi yang capable mengelola dan menghasilkan sumber daya manusia yang bermutu (Wibowo, 2013:1). Perguruan Tinggi juga harus mampu mengkonstruktivitaskan institusinya secara moral dan manajerial agar ia dapat survive dan mampu menyediakan semua proses intelektualisasi produk yang dihasilkannya kepada masyarakat secara sistematis,continue dan sesuai dengan tuntutan dan kebutuhan masyarakat tentang harapan dan cita-citanya mendapatkan manfaat belajar di perguruan tinggi.

Peran tersebut di ataslah yang pada akhirnya mendudukkan perguruan tinggi sebagai Menara gading. Suatu cita-cita yang senantiasa terus dikejar oleh masyarakat untuk menapaki eksistensi kehidupannya dalam komunitas kegiatan bermasyarakat, berbangsa, dan bernegara. Dengan kata lain, perguruan tinggi sampai hari ini merupakan jalan elementer bagi masyarakat dalam upayanya menjadikannya kaum elit- kelompok masyarakat yang memberikan pengaruh, dan daya dorong kuat sekaligus juga sebagai pemimpin di tengah suatu komunitas masyarakat. Apapun komunitasnya, apakah komunitas politik, ekonomi,sosial, budaya, profesi dan sebagainya.

Lulusan perguruan tinggi, tulis Agus Wibowo (2012:131), diharapkan mampu menjalankan fungsinya sebagai agen pembaharu dalam masyarakat (agent of social change), di antaranya dalam pemahaman dan pemikiran masyarakat yang terbuka dan cerdas dalam bidang apapun; seperti politik, hukum, pendidikan, kesehatan, keagamaan dan dimensi lainnya. Lulusan perguruan tinggi juga diharapkan membawa pencerahan dan memberikan pengaruh positif bagi peningkatan taraf hidup dan kesejahteraan masyarakat (Dikti, 2007). Harapan masyarakat yang begitu menggebu terhadap lulusan perguruan tinggi cukup beralasan. Karena kalua bukan lulusan perguruan tinggi siapa lagi yang memberikan pencerahan,pembaruan, dan peningkatan taraf hidup mereka. Namun keinginan masyarakat agar lulusan perguruan tinggi berkualitas dan mampu melakukan yang terbaik baginya, ternyata akhir-akhir ini tinggal harapan. Kenapa? Selama ini kualitas lulusan perguruan tinggi pada skala nasional maupun daerah cukup mengkhawatirkan. Jumlah lulusan yang memiliki kualitas yang dapat dipertanggungjawabkan secara akademik kepada masyarakat cukup kecil.

Hal inilah yang menyebabkan masyarakat sering memiliki pandangan miring kepada lulusan perguruan tinggi. Masyarakat menemukan sebagian besar lulusan perguruan tinggi tidak mampu menjalankan misinya sebagai orang yang terdidik, memiliki ilmu pengetahuan dan memiliki nilai (values) yang menjadi identitas sebagai kaum terdidik. Rendahnya values baik berupa nilai agama dan etika, juga telah memperparah keberadaan lulusan perguruan tinggi di mata masyarakat.(Andi Trinanda,2007; dalam Wibowo, 2013:3).

Di sisi lain, persyaratan dunia kerja saat ini tidak hanya pada pengetahuan dan ketrampilan saja (knowledge and skills), tetapi juga menyangkut karakter, perilaku dan sikap mahasiswa, serta mengenal sifat pekerjaan atau terlatih dengan etika kerja. Karena itulah pendidikan tinggi saat ini semestinya tidak hanya sekedar menyiapkan tenaga kerja yang pandai dan terampil, tetapi juga memiliki karakter yang kuat (Wibowo,2013:3). 


\section{PEMBAHASAN}

\subsection{Mengapa Pendidikan \\ Karakter}

Pendidikan karakter adalah proses pemberian tuntunan kepada peserta didik untuk menjadi manusia seutuhnya yang berkarakter dalam dimensi hati,pikir, raga, serta rasa dan karsa. Pendidikan karakter dapat dimaknai sebagai pendidikan nilai, pendidikan budi pekerti, pendidikan moral, pendidikan watak, yang bertujuan mengembangkan kemampuan peserta didik untuk memberikan keputusan baik- buruk, memelihara apa yang baik, dan mewujudkan kebaikan itu dalam kehidupan sehari-hari dengan sepenuh hati (Samani Muchlas, 2012:45).

Indonesia saat ini menghadapi dua tantangan besar, yaitu desentralisasi atau otonomi daerah yang saat ini sudah dimulai, dan era globalisasi total yang akan terjadi pada tahun2020. Kedua tantangan tersebut merupakan ujian berat yang harus dilalui dan dipersiapkan oleh seluruh bangsa Indonesia. Kunci sukses dalam menghadapi tantangan berat itu terletak pada kualitas sumberdaya manusia (SDM) Indonesia yang handal dan berbudaya. Oleh karena itu, peningkatan kualitas SDM sejak dini merupakan hal penting yang harus dipikirkan secara sungguh-sungguh (Muslich, 2011:35).

Karakter bangsa merupakan aspek penting dari kualitas SDM karena kualitas karakter bangsa menentukan kemajuan suatu bangsa. Thomas Lickona, seorang professor pendidikan dari Cortland University, mengungkapkan bahwa ada sepuluh tanda-tanda zaman yang harus diwaspadai karena jika tanda-tanda ini sudah ada, berarti sebuah bangsa sedang menuju jurang kehancuran.Tanda-tanda yang dimaksud adalah (1) meningkatnya kekerasan di kalangan remaja,(2) penggunaan Bahasa dan kata-kata yang memburuk,(3) pengaruh peer-group yang kuat dalam tindak kekerasan,(4) meningkatnya perilaku merusak diri, seperti penggunaan narkoba, alcohol, dan seks bebas, (5) semakin kaburnya pedoman moral baik dan buruk,(6) menurunnya etos kerja,(7) semakin rendahnya rasa hormat kepada orang tua dan guru, (8)rendahnya rasa tanggung jawab individu dan warga negara, (9) membudayanya ketidak jujuran, dan (10) adanya rasa saling curiga dan kebencian di antara sesama. Jika dicermati, ternyata kesepuluh tanda zaman tersebut sudah ada di Indonesia (Muslich,2011: 35-36).

Pembentukan Karakter harus dilakukan secara sistematis dan berkesinambungan yang melibatkan aspek knowledge, feeling, loving, dan action Pembentukan karakter dapat diibaratkan sebagai pembentukan seseorang menjadi body builder (binaragawan) yang memerlukan latihan otot-otot akhlak secara terus menerus agar menjadi kokoh dan kuat. Thomas Lickona dalam (Muslich, 2011) mendefinisikan orang yang berkarakter sebagai sifat alami seseorang dalam merespons situasi secara bermoral, yang dimanifestasikan dalam tindakan nyata melalui tingkah laku yang baik, jujur, bertanggung jawab, menghormati orang lain dan karakter mulia lainnya. Pengertian ini mirip dengan apa yang diungkapkan oleh Aristoteles bahwa karakter itu erat kaitannya dengan habit atau kebiasaan yang terus menerus dilakukan.

\subsection{Tujuan Pendidikan Karakter}

Pendidikan karakter bertujuan untuk meningkatkan mutu proses dan hasil pendidikan yang mengarah pada pembentukan karakter dan akhlak mulia peserta 
didik secara utuh, terpadu, dan seimbang, sesuai dengan standar kompetensi lulusan pada setiap satuan pendidikan. Melalui pendidikan karakter peserta didik diharapkan mampu secara mandiri meningkatkan dan menggunakan pengetahuannya, mengkaji dan menginternalisasikan serta mempersonalisasikan nilai-nilai karakter dan akhlak mulia sehingga terwujud dalam perilaku sehari-hari (Mulyasa, 2012:9). Pendidikan karakter pada tingkat perguruan tinggi mengarah pada pembentukan budaya kampus, yaitu nilai-nilai yang melandasi perilaku, tradisi, kebiasaan sehari-hari, serta simbol-simbol yang dipraktikkan oleh semua warga kampus, dan masyarakat sekitarnya. Budaya kampus merupakan ciri khas, karakter atau watak, dan citra kampus tersebut di mata masyarakat luas.

\subsection{Karakter Ideal Mahasiswa}

Mahasiswa dan generasi muda pada umumnya adalah harapan bangsa. Di era globalisasi dan krisis multidimensional yang berkepanjangan saat ini bangsa kita membutuhkan para mahasiswa dan pemuda yang tanggap masalah, tangguh, berkarakter kuat dan berjiwa kesatria sejati. Seorang kesatria itu tidak akan pernah ingkar janji; baginya mati demi mempertahankan kebenaran, keyakinan diri dan janji, derajatnya lebih mulia ketimbang hidup bergelimang kemewahan, tetapi menjadi penjilat dan pengekor. Mahasiswa sebagai sosok kesatria demikian, memiliki sifat-sifat luhur seperti kreatif,pantang menyerah, pembrani, visioner, problem solver, memiliki jiwa leadership yang baik, komitmen kuat pada nasionalisme kebangsaan, dan memegang nilai-nilai kebenaran di atas segalagalanya (Wibowo, 2013:48).

Sementara itu, peran mahasiswa dan pemuda dalam konteks kenegaraan tidak lagi diukur dengan kontribusi fisik layaknya era perang kemerdekaan. Sebab, tantangan kebangsaan yang di hadapi saat ini jauh berbeda. Artinya, tantangan terbesar dari perjuangan para mahasiswa dan pemuda saat ini adalah menghapus penjajahan bangsa dan negara dari kolusi, korupsi dan nepotisme (KKN). Mahasiswa dan pemuda ideal saat ini, mereka tidak akan mampu melaksanakan tugas berat memberantas KKN tanpa adanya komitmen yang tinggi.Peran mahasiswa dan pemuda saat ini berada pada ujian yang berat, fase kritis untuk tetap tampil menjadi tulang punggung bangsa dalam mengawal gerak reformasi. Maka para mahasiswa dan pemuda tersebut harus memiliki sifat- sifat ideal,plus kendaraan strategis berupa hati nurani (Wibowo,2013:51).

Adapun nilai-nilai yang perlu dikembangkan melalui pendidikan karakter meliputi:

a. Ketaatan beribadah, yakni pikiran, perkataan dan tindakan seseorang yang diupayakan untuk selalu menjalankan ajaran agamanya.

b. Kejujuran, yakni sikap dan prilaku seseorang yang didasarkan pada upaya menjadikan dirinya selalu dapat dipercaya dalam perkataan dan perbuatannya.

c. Tanggung jawab, yakni sikap dan prilaku seseorang untuk melaksanakan tugas dan kewajibannya sebagaimana yang seharusnya dia lakukan, baik terhadap diri sendiri,masyarakat,lingkungan,negara maupun Tuhan Yang Maha Esa.

d. Kedisiplinan, yakni sikap dan prilaku yang menunjukkan ketertiban dan kepatuhan terhadap berbagai ketentuan dan peraturan. 
e. Etos kerja, yakni sikap dan prilaku seseorang yang menunjukkan semangat dan kesungguhan dalam melakukan suatu pekerjaan. Karakter inilah yang sekarang terwujud melalui kerjasama, yakni sikap dan prilaku yang menunjukkan upaya dalam melakukan suatu pekerjaan bersama-sama secara sinergis.

f. Kemandirian, yakni sikap dan perilaku yang tidak mudah tergantung pada orang lain dalam menyelesaikan tugas-tugas.

g. Sinergi, yakni sikap dan perilaku yang menunjukkan upaya-upaya untuk memasukkan berbagai pekerjaan yang dilakukan.

h. Kritis, yakni sikap dan perilaku yang berusaha untuk menemukan kesalahan atau kelemahan maupun kelebihan dari suatu perbuatan.

i. Kreatif dan inovatif, yakni berpikir dan melakukan sesuatu untuk menghasilkan cara atau hasil baru dan termutakhir dari apa yang telah dimiliki.

j. Visioner, yakni pandangan, wawasan, dan kemampuan seseorang untuk membangun kehidupan masa depan yang lebih baik.

k. Kasih sayang dan kepedulian, yakni sikap dan perilaku seseorang yang menunjukkan suatu perbuatan atas dasar cinta dan perhatian kepada orang lain maupun kepada lingkungan dan proses yang terjadi disekitarnya.

1. Keiklasan, yakni sikap dan perilaku seseorang untuk melakukan suatu perbuatan dengan ketulusan hatinya.

m. Keadilan, yakni sikap dan perilaku seseorang yang menunjukkan upaya untuk melakukan perbuatan yang sepatutnya sehingga terhindar dari perbuatan yang semena-mena dan berat sebelah.

n. Kesederhanaan, yakni sikap dan perilaku yang menunjukkan kesahajaan dan tidak berlebihan dalam berbagai hal.

o. Nasionalisme, yakni cara berpikir, bersikap, dan berbuat yang menunjukkan kesetiaan, kepedulian dan penghargaan yang tinggi terhadap Bahasa, lingkungan fisik, sosial, budaya, ekonomi, dan politik bangsanya.

p. Internasionalisme, yakni cara berpikir, bersikap, dan berbuat seseorang yang menunjukkan bahwa bangsa dan negaranya merupakan bagian dari dunia sehingga terdorong untuk mempertahankan dan memajukannya sehingga dapat berkiprah di dunia internasional.

(Wibowo Agus,2013:139).

Ketaatan beribadah, kejujuran, desiplin, dan tanggungjawab merupakan pembentukan karakter yang tidak dapat dilakukan secara instan. Hal itu sudah dimulai semenjak bayi dalam kandungan. Oleh karena sifat kejujuran, desiplin dan bertanggungjawab secara dini disadari untuk dimulai. Hal itu hanya dapat terlaksana apabila ada penyadaran tentang pemahaman karakter itu sendiri. Keluarga adalah tempat yang sangat penting dalam menumbuhkan karakter. Oleh karena keluarga memiliki peranan penting di dalam pembentukan sifat dasar seseorang. Keluarga yang sehat menjadi hal penting untuk diperhatikan. Menanamkan jiwa desiplin juga dimulai dari keluarga.Kesadaran desiplin akan mulai dapat dirasakan bila berada pada situasi kondisi keluarga normal. Ibadah merupakan hal utama untuk mengingatkan takdir manusia, ibadah dapat memperhalus jiwa dan menekan egositas manusia. Oleh karenanya semenjak dini belajar ibadah menjadi hal utama perlu disadari oleh generasi bangsa. Hal itu terus 
ditumbuh kembangkan sehingga di dalam usia yang semakin mapan karakter yang dikehendaki menjadi turut berkembang di dalamnya.

Masyarakat adalah wadah sosial yang kemudian mematangkan dan memberikan fungsi terhadap karater yang telah dipelajari. Tanpa masyarakat tujuan untuk mempraktikan karakter menjadi tidak berguna oleh karena karakter seseorang akan digunakan ketika sudah dihadapkan pada nilai dan norma. Nilai dan norma juga akan bisa berlaku jika ada masyarakat. Oleh karenanya pertemuan dan hubungan sosial sesungguhnya telah membawa kehidupan bermasyarakat menjadi berguna. Masyarakat beradab adalah masyarakat yang mampu berkarakter baik. Semakin banyak orang-orang menyadari sedari awal tentang karakter yang baik maka tidak pelanggaran tentang aturan bermasyarakat menjadi lebih baik. Kejujuran dan desiplin akan terlahir dari karakter dan kesadaran yang baik.

Dalam konteks bernegara karakter masyarakat sangat penting diharapkan untuk menumbuhkan masyarakat yang berkepribadian. Artinya kemajuan suatu negara sangat didasarkan pada sikap dan perilaku yang berkarakter baik. Hal itu disebabkan di dalam proses bernegara kedaulatan rakyat adalah hal utama artinya membangun masyarakat bawah adalah tanggungjawab utama. Bila kesadaran itu sudah dipahami secara bersama, maka tingkat pelaksanaan pencapaian tujuan setidaknya akan lebih mudah dicapai.Bukan untuk membangun kepentingan golongan dan individu di atas penderitaan rakyat.

Keberhasilan membangun warga yang berkepribadian memiliki ciri dan memiliki kesadaran untuk membangun mental yang jujur. Hal yang paling menonjol dalam kehidupan berbangsa adalah meningkatkan perilaku jujur untuk memerangi korupsi. Salah satu tanda-tanda ketidakberhasilan membangun waraganegara yang tidak berkarakter adalah suburnya tingkat korupsi. Hal itu tidak saja merugikan negara dan rakyat namun juga melemahkan kepercayaan rakyat bawah. Dampak korupsi sangat menakutkan oleh karena kesejahteraan rakyat yang tertunda saat ini lebih diakibatkan oleh lemahnya karakter bangsa.

Dengan demikian dapat dikatakan bahwa proses pemahaman karakter bangsa membutuhkan kesadaran. Memperoleh kesadaran hanya dapat dilakukan dengan cara turut terlibat dalam proses aktivitas kegiatan masyarakat. Menyadarkan bahwa di dalam mencapai keadilan maka karakter yang berkepribadian menjadi hal utama yang tidak dapat disepelekan. Mahasiswa adalah agen penting di dalam menjaga kemajuan bangsa oleh karenanya pada masa pembelajaran karakter tidak boleh disepelekan agar diperoleh hasil yang baik.

\section{PENUTUP}

Lulusan perguruan tinggi, diharapkan mampu menjalankan fungsinya sebagai agen pembaharu dalam masyarakat (agent of social change), di antaranya dalam pemahaman dan pemikiran masyarakat yang terbuka dan cerdas dalam bidang apapun; seperti politik, hukum, pendidikan, kesehatan, keagamaan dan dimensi lainnya. Lulusan perguruan tinggi juga diharapkan membawa pencerahan dan memberikan pengaruh positif bagi peningkatan taraf hidup dan kesejahteraan masyarakat. Mahasiswa dan generasi muda pada umumnya adalah harapan bangsa. Di era globalisasi dan krisis multidimensional yang berkepanjangan saat 
ini bangsa kita membutuhkan para mahasiswa dan pemuda yang tanggap masalah, tangguh, berkarakter kuat dan berjiwa kesatria sejati. Mahasiswa harus memiliki karakter yang kuat. Untuk itu perlu dikembangkan nilai-nilai seperti: ketaatan beribadah, kejujuran, tanggung jawab, kedisiplinan, etos kerja, kemandirian, sinergi, kritis, kreatif dan inovatif, visioner, kasih sayang dan kepedulian, keiklasan, keadilan, kesederhanaan, nasionalisme, dan internasionalisme.

\section{DAFTAR PUSTAKA}

Muchlas, Samani. 2012. Konsep dan Model Pendidikan Karakter. Bandung: PT. Remaja Rosdakarya.

Mulyasa. 2012. Manajemen Pendidikan Karakter. Jakarta: Bumi Aksara.

Muslich, Masnur. 2011. Pendidikan Karakter Menjawab Tantangan Krisis Multidimensional. Jakarta: Bumi Aksara.

Wibowo, Agus. 2013. Pendidikan Karakter di Perguruan Tinggi. Yogyakarta: Pustaka Pelajar. 